\title{
HUMAN RESOURCES IN PUBLIC ADMINISTRATION
}

\section{LIDSKÉ ZDROJE VE VEŘEJNÉ SPRÁVĚ}

\section{ING. LIBUŠE MĚRTLOVÁ, PH.D.}

\author{
MGR. ZdeŇKa DOSTÁLOVÁ \\ Katedra ekonomických studii $\mid$ Department of Economic Studies \\ Vysoká škola polytechnická Jihlava The College of Polytechnics Jihlava \\ $\triangle$ Tolstého 16, 58600 Jihlava, Czech Republic \\ E-mail:mertlova@vspj.cz,dostalova@vspj.cz
}

\begin{abstract}
Anotace
Článek informuje o výsledcich výzkumu probíhajicího v rámci interniho grantu VŠP Jihlava, který je zaměrený na zkoumáni efektivnosti ve veřejné správě, a to z pohledu samotných pracovníkủ úradu. Výzkum je rozdèlen do 3 etap, které probihhaly postupně ve velkých organizacích veřejné správy s výkonem samosprávy i státni správy v přenesené působnosti. Výzkum probihal na podkladè dotazniků, které byly předány pracovnikuim úřadu, kteři byli vybráni náhodným výběrem a anonymně odpovídali na 60 otázek rozdělených do šesti okruhü: lidské zdroje, organizačni kapitál, informačni kapitál, zákaznický kapitál, mérení výkonnosti a inovačni kapitál. Respondenti provádèli hodnocení situace v úr̆adu na základè vlastního posouzení. Cílem tohoto přispěvku je informovat o výsledcích výzkumu zejména z pohledu lidského, organizačního a sociálního kapitálu v organizacích veřejné správy.
\end{abstract}

\section{Klíčová slova}

veřejná správa, lidské zdroje, organizačni kapitál, informačni kapitál, zákaznický kapitál, měřeni výkonnosti, inovačni kapitál

\section{Annotation}

The article informs about results of a research taking place within an internal grant of College of Polytechnics Jihlava, which is aimed at examining the efficiency in public administration from the point of view of the office workers themselves. The research took place in the form of questionnaires given to randomly chosen workers of the offices who anonymously answered 60 questions divided into six topics: human resources, organisational capital, information capital, customer capital, performance measuring and innovation capital. The aim of the paper is to inform about the results of this research especially from the point of view human capital, organizational capital and social capital in organisations of public administration.

\section{Key words}

public administration, human resources, organisational capital, information capital, customer capital, performance measuring, innovation capital

JEL classification: $H 11$

\section{Introduction}

With the arrival of the era of the knowledge society, the primary source of economic growth was no longer represented by natural resources and physical labour but by information and knowledge. The term new economy was coined, meaning information, network, digital, and knowledge economy. (Truneček, 2001). 
Companies providing services, especially those demanding on knowledge, started to achieve higher profits, higher market value than companies in traditional production branches of economy. Investments started to be made into intangible assets like research and development, staff education and development, creating corresponding company culture and strong customer orientation in terms of maximal satisfaction of customer needs during selling, providing services, and the follow-up service.

An important step was taken in the research project Meritum, which was intended to:

- Set a single classification pattern for intangible assets,

- Document a system of management and control of companies in order to identify common European practices in measuring intangible assets,

- Evaluate the importance of intangible assets for capital markets working by means of market information analysis,

- Create guidelines for measuring and presenting intangible assets (Dvořáková, 2007).

This task was accomplished and it resulted in Guideline for Controlling and Presenting Intangible Assets. This guideline defines intellectual capital as a combination of human capital, structural capital, and social capital (OECD, 1999).

People and their creative abilities in using other sources - material and financial - are the decisive factor of each company's development, both in the entrepreneurial sector and in the area of public sector. For that reason, especially large companies and companies with international capital pay the greatest attention to issues connected with raising qualification, teambuilding, with the emphasis on the flexibility of workers and their high work enthusiasm and loyalty to the employer.

These tendencies manifest themselves in the area of public administration as well, because modern public administration is the most dynamic element of institutional and functional development of the modern state itself. On that account constant changes and innovations are taking place in public administration with the goal to modernize it and adjust it to the current requirements for high quality and economical execution of demanded administration and to comply with the citizens' wishes in terms of increasing the comfort of providing services and minimizing time and financial costs. This intention is closely related with the evaluation of the public administration performance, which has been dealt with in a number of developed countries for about the last twenty years in the context of both the effort to increase the efficiency of public administration and the attempt to strengthen its democratic monitoring by the public - its larger capacity of public demonstration (Illner, Kostelecký, Patočková, 2007).

In 2006 the government of the CR passed the strategy Efficient Public Administration and Friendly Public Services - Smart Administration for the realization period 2007 to 2015. Its goal is to ensure a coordinated and efficient way of improving public administration and public services using the finance from the structural funds in the programme period 2007-2013. The goal is to be reached through coordination and synergic activities within the Human Resources OP, the Integrated Operational Programme and national resources (Smart administration, 2007).

\section{Material and methods}

The intention of the research was to address large organizations of public administration in the region and arrange for the implementation of a research which would bring answers in the form of either confirming or disproving of hypotheses aimed at overall evaluation of the level of public administration in the examined organizations. They were the Jihlava Town Council, the Regional Authority of the Vysočina Region, twenty-five selected municipalities and twenty-five detached workplaces of state administration in the Vysočina Region. The research was divided into two parts, when in the first part employees themselves carried out evaluation of their own work and conditions for public administration execution. In the other part the research was aimed at clients leaving an office and evaluated their satisfaction with the work of officers during public administration activities and communication with clients. 
The presented results are from the first part of the research. The total of 103 respondents was addressed, which represents $30 \%$ employees of the organizations where the research took place. The questionnaires were filled in by 98 respondents, which means $95.15 \%$. The stated results refer to the topics of Human Resources, Basic Capital, Organizational Capital, and Innovation Capital. These are topics that include fundamental areas of the company's intellectual capital. The results published in this article are intended to point out the best and, on the contrary, the most problematic topics of evaluation. An organization is not indicated directly, it is marked organization I.

\section{Results and discussion}

\section{Human resources}

The first five questions from this topic were focused on judging the level of education in an organization when the first one was oriented at processing the programme of employee education, the second one at assessing education programmes, the third one at educational methods, the fourth at finding out employee satisfaction with education and qualification increasing, and the fifth at recording the number of days spent by training. The following two questions $\left(6^{\text {th }}\right.$ and $\left.7^{\text {th }}\right)$ find out whether the organization has defined important values, whether these values are accepted by employees and whether they share them. The next two questions $\left(8^{\text {th }}\right.$ and $\left.9^{\text {th }}\right)$ examine whether there is a system of employee performance evaluation and a system of work performance management introduced. The last, tenth question is aimed at the level of communication in the organization.

\section{Tab. 1: Answers of organization I employees - Human Resources}

\begin{tabular}{|l|c|c|c|c|}
\hline Answers & yes & no & other options according to question & without answer \\
\hline question 1 & 97 & 0 & 0 & 1 \\
\hline question 2 & 88 & 8 & 0 & 2 \\
\hline question 3 & 0 & 38 & 58 & 2 \\
\hline question 4 & 93 & 3 & 0 & 2 \\
\hline question 5 & 96 & 0 & 0 & 2 \\
\hline question 6 & 70 & 13 & 0 & 15 \\
\hline question 7 & 67 & 8 & 0 & 23 \\
\hline question 8 & 66 & 18 & 0 & 14 \\
\hline question 9 & 63 & 20 & 0 & 15 \\
\hline question 10 & 48 & 38 & 12 & 0 \\
\hline
\end{tabular}

Source: own research

Fig. 1: Answers of organization I employees - Human Resources

Yes $\square$ No 0 ther possibility $\square$ Without answers

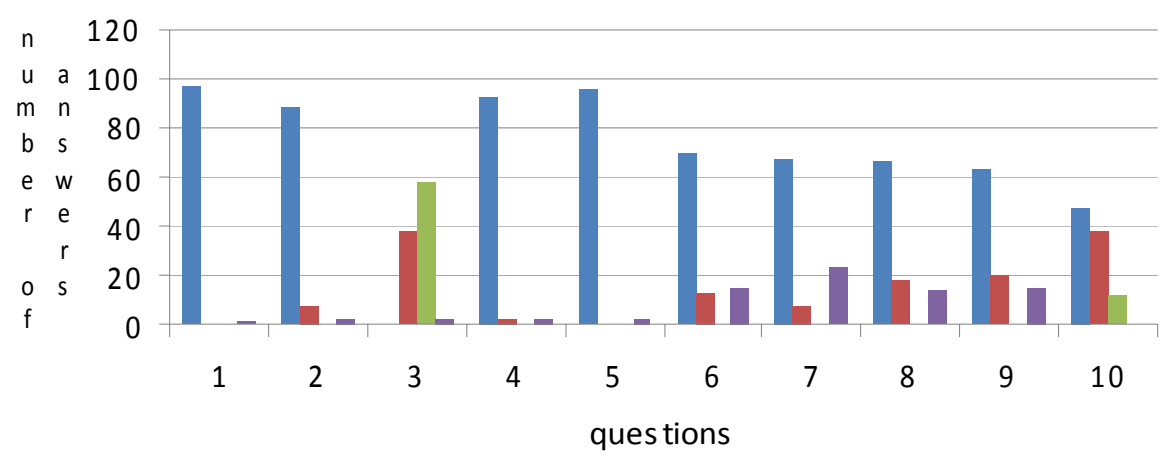

Source: own research 


\section{Customer capital}

Customer capital, its examination and feedback that should follow are definitely one of the most important issues of both each research dealing with the efficiency of a company's operation and the follow-up implementation of measures for improvement in problem areas. The first question was focused on the form of communication with the client with the options of personal communication, mediated or non-contact one, the second question dealt with the perception of the activity of the office by the public as welcome, publicly needed or a necessary evil. The third question examined whether the organization implements marketing and advertising events, the fourth one evaluates the approach to the client, whether workers are interested in solving the client's requirement, and the fifth question monitors whether customer satisfaction surveys are carried out. In the sixth question employees answered the question whether they are informed with the results of these surveys. The seventh question examines whether the organization carries out customer needs surveys. The eighth question studies whether the office's website is kept updated, the ninth question then judges whether the activity of workers provides a complex solution to the clients' problems, and the tenth question evaluates whether information materials are available at the office.

Tab. 2: Answers of organization I employees-Customer capital

\begin{tabular}{|l|c|c|c|c|}
\hline Answers & yes & no & other options according to question & without answer \\
\hline question 1 & 74 & 8 & 1 & 15 \\
\hline question 2 & 7 & 69 & 22 & 0 \\
\hline question 3 & 18 & 68 & 0 & 12 \\
\hline question 4 & 88 & 1 & 0 & 9 \\
\hline question 5 & 12 & 76 & 0 & 10 \\
\hline question 6 & 10 & 59 & 0 & 29 \\
\hline question 7 & 19 & 58 & 0 & 21 \\
\hline question 8 & 89 & 2 & 3 & 7 \\
\hline question 9 & 72 & 11 & 0 & 12 \\
\hline question 10 & 68 & 17 & & Source: own research \\
\hline
\end{tabular}

Fig. 2: Answers of organization I employees - Customer capital

Yes No 0 ther possibility W W ithout answers

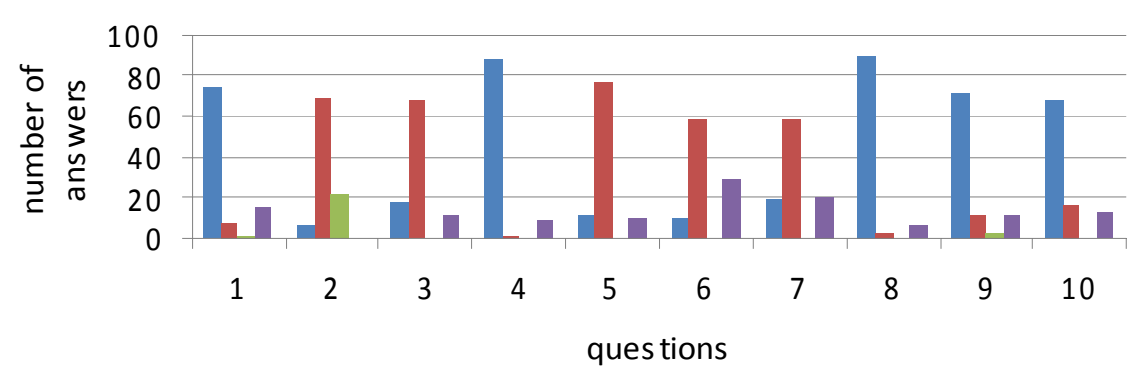

Source: own research

\section{Organizational capital}

The first question examined whether the organization is able to respond to new conditions of the environment, the second one concerned the style of subordinate workers management autocratic, democratic, or liberal, the third question studies whether the manager is able to help 
subordinate in solving problems. Question 4 was aimed at personal responsibility of officers (options: I bear/ don't bear responsibility, both decision-making and responsibility are collective), the fifth question examines whether the worker directly manages subordinates. The following three questions are focused on organization chart of the organization, when the sixth question studies the number of levels $-1,2$, or 3 levels, the seventh one monitors whether team building is possible and the eighth one examines whether the organization chart enables flexibility in problem solving. The ninth question inquires whether there are regular meetings of managers with workers and the tenth one is aimed at monitoring how informed the workers are about the organization's strategy, vision and mission.Good evaluation was chosen from the options of the reaction to new conditions in the environment, the possibilities of teambuilding across the organization, and the possibilities of applying new methods of work in the organization. According to the respondents, democratic management style prevails in the organization, with workers usually not bearing personal responsibility for their decisions, which also corresponds with the fact that they do not mostly manage subordinate workers. Most respondents know the organization chart of the organization (question 6), they perceive is as a multi-level structure that facilitates teambuilding and ensures flexibility in problem solving. Regular holding of meetings (question 9) is evaluated positively with 84 respondents stating that in their answers. On the other hand, the responses to the last question about strategy, vision, and mission of the organization show that there are considerable reserves in the communication of management and workers in the area of strategy, vision, and mission. This automatically means also reserves in workers' loyalty, their personal involvement and approach to the activity of the organization as a whole. Detailed results are presented in table and graph 3.

Tab. 3: Answers of employees - Organisational capital

\begin{tabular}{|l|c|c|c|c|}
\hline Answers & yes & no & other options according to question & without answer \\
\hline question 1 & 89 & 4 & 0 & 5 \\
\hline question 2 & 23 & 58 & 11 & 6 \\
\hline question 3 & 76 & 3 & 17 & 2 \\
\hline question 4 & 7 & 89 & 1 & 1 \\
\hline question 5 & 17 & 77 & 0 & 4 \\
\hline question 6 & 2 & 4 & 81 & 11 \\
\hline question 7 & 71 & 14 & 0 & 13 \\
\hline question 8 & 74 & 13 & 0 & 11 \\
\hline question 9 & 84 & 13 & 0 & 1 \\
\hline question 10 & 66 & 18 & 0 & 1 \\
\hline
\end{tabular}

Fig. 3: Answers of organization I employees - Organizational capital

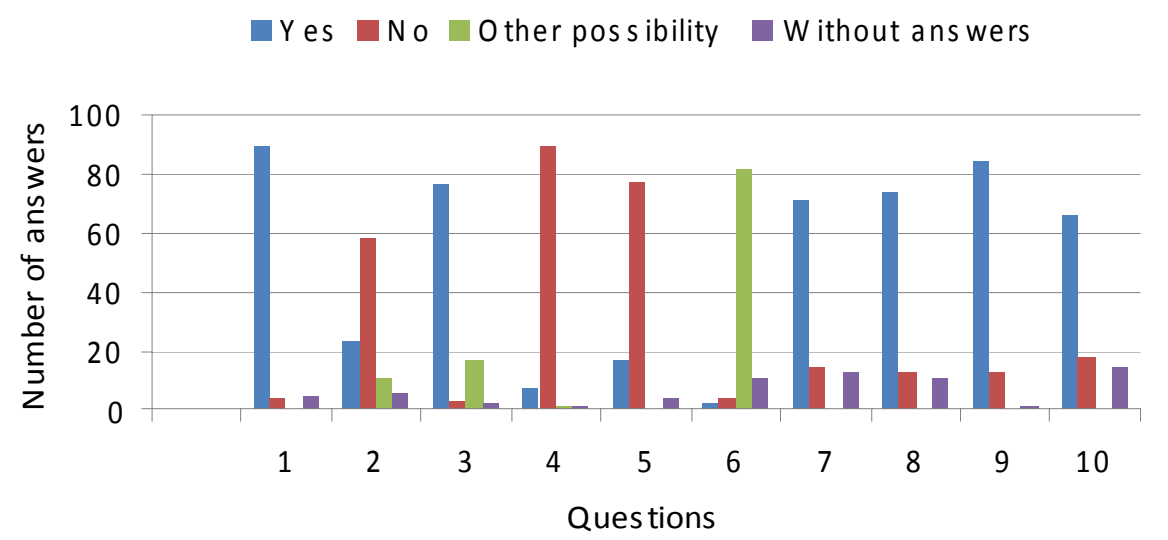

Source: own research 


\section{Innovation capital}

The first question examined the possibility to apply innovation elements of work in the organization; the second one was aimed at the possibility of personal influencing of innovation implementation. The third question inquired whether there is a stand-alone unit in the organization with the role to apply innovations. The fourth question studied whether the organization uses the CAF method of selfevaluation, the fifth one mapped whether the efficiency of innovation changes is evaluated and in the positive case, what the frequency of evaluation is. The sixth question continued with the question whether employees are informed about the results of this evaluation and in the seventh question there was an inquiry whether employees are rewarded for suggesting a new approach or improvement in the performed work. The eighth question was aimed at a client, that is whether clients can suggest innovation procedures for officer work improvement as well. The ninth question examined the usability of new innovative procedures also in other parts of the organization and the tenth monitored whether the public is informed about the innovation in the organization.

Table 4: Answers of organization I employees - Innovation capital

\begin{tabular}{|l|c|c|c|c|}
\hline Answers & yes & no & Other options & Without answer \\
\hline question 1 & 66 & 19 & 0 & 13 \\
\hline question 2 & 15 & 43 & 28 & 12 \\
\hline question 3 & 15 & 68 & 0 & 15 \\
\hline question 4 & 1 & 76 & 0 & 21 \\
\hline question 5 & 9 & 64 & 3 & 22 \\
\hline question 6 & 6 & 54 & 0 & 38 \\
\hline question 7 & 23 & 61 & 0 & 14 \\
\hline question 8 & 16 & 65 & 0 & 17 \\
\hline question 9 & 6 & 20 & 39 & 33 \\
\hline question 10 & 51 & 25 & 0 & 22 \\
\hline
\end{tabular}

\section{Graph 4: Answers of organization I employees - Innovation capital}

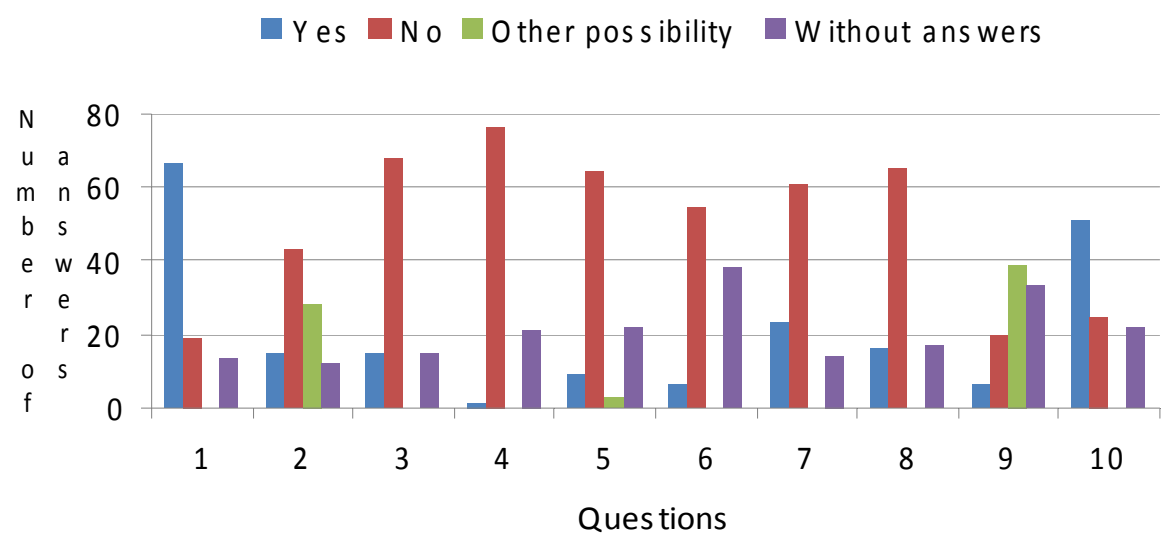

Source: own research

\section{Conclusion}

The published paper summarizes the results of the first stage of the research carried out in the public administration organization in the Vysočina Region dealing with human resources, customer, organizational and innovation capital. 
The results can be summed up into the following conclusions:

While evaluating human capital from the point of view of qualification and education, the assessment of all questions was distinctively positive. The reserves of the organization's human capital lie especially in the area of communication and sharing the organization's values, in the system of assessing work performance, and consequently also in work performance management. The issue of communication inside the organization is a problem that it is necessary to solve as soon as possible, namely e.g. by the choice of suitable seminars or by implementing education financed from the European Social Funds.

In case of customer capital the largest reserves can be seen in higher interest in the public, introducing holding marketing events of the organization (although there are discussions whether they are suitable in public administration), introducing regular satisfaction surveys of clients who are leaving the office and surveys of needs of the clients who are coming to the office. Then, it is necessary to continue working with the results of these surveys and to provide employees with feedback that will ensure improvement of the level of services provided.

In the evaluation of organizational capital it is necessary to give positive evaluation to the possibility of the company's conforming to the changing condition, the possibility of building work teams and the prevailing democratic style of management. The area for improvement is definitely in increasing personal responsibility in implementing work tasks, a possible reduction of levels in the organizational chart of the (multilevel) organization, and improving the communication of the organization's strategy, vision, and mission to its employees.

Innovation capital of the organization is the area that received the worst evaluation. Low possibility of personal influencing innovation implementation as well as insufficient evaluation of innovation changes efficiency, providing workers in this area with no feedback and insufficient motivation of employees to suggest new methods of work are issues that the organization should consider and try to put right. It is necessary to ensure early responses to workers' requirements in using modern methods of work and in implementing innovative procedures to the office's activities as well as in implementing new methods of work performance evaluation and in selfevaluation of employees' work.

\section{Literature}

[1] DVOŘÁKOVÁ. Z. a kol. Management lidských zdrojů. Praha: Nakladatelství Beck, 2007. ISBN 978-80-7179-893-4

[2] ILLNER, M., KOSTELECKÝ, T., PATOČKOVÁ, V. Jak fungují kraje - př́spěvek k hodnocení výkonu krajských vlád. Sociologický časopis / Czech Sociological Review, 2007, č.43 (5), s. $967-$ 992, ISSN 0038-0288.

[3] OECD. Guidelines and Instructions for OECD Symposium. International Symposium Measuring and Reporting Intellectual Capital: Experiences, Issues, and Prospects. Amsterdam, Paris:1999.

[4] Smart administration (SA) - Strategie Vlády ČR. Efektivni veřejná správa a prátelské veřejné služby. Strategie realizace Smart Administration 2007-2015 (usnesení vlády ze dne 11. července 2007, č. 757).

[5] TRUNEČEK, J. Systémy řizeni podniku ve společnosti znalostí. Praha: VŠE, 2001. ISBN 807179-884-3.

This paper was created as an output of an internal grant project of College of Polytechnics Jihlava named Research of the Efficiency of Public Administration Operation, carried out in public administration organizations in the Vysočina Region in 2011. 